\title{
Pecalang Covid-19: Satuan Tugas Keamanan Tradisional dalam Mencegah Penyebaran Virus Corona
}

\author{
Carolina Augi Widya Putri ${ }^{1}$, Ni Wayan Desi Budha Jayanti ${ }^{1}$, Putu Novita Dewi Lestari ${ }^{1}$, \\ Bayu Adhinata ${ }^{1 *}$
}

${ }^{1}$ Universitas Warmadewa, Indonesia

\author{
A R T I C L E I N F O \\ Article history: \\ Received 15 October 2021 \\ Accepted 23 November \\ 2021 \\ Available online 01 \\ December 2021 \\ Kata Kunci: \\ Covid-19; Pecalang; Tugas \\ dan Fungsi \\ Keywords: \\ Covid-19; Pecalang; Job and \\ Function
}

\begin{abstract}
A B S T R A K
Pada tahun 2020 tepatnya di bulan Maret, Indonesia dikejutkan dengan adanya Covid-19 yang menelan banyak korban jiwa sehingga pemerintah terus berupaya membuat kebijakan demi kebijakan untuk memutus rantai Covid-19. Berdasarkan hal tersebut pemerintah Provinsi Bali melibatkan Desa Pekraman dengan memberdayakan Pecalang. Penelitian ini bertujuan untuk mengetahui cara Pecalang menjalankan fungsi dan tugas sebagai satgas keamanan tradisional dalam penanganan penyebaran Covid-19 di Desa Pekraman Denpasar. Metode penelitian yang digunakan deskriptif kualitatif. Data yang diperoleh berasal dari hasil observasi, wawancara mendalam, dan studi pustaka. Hasil penelitian menunjukkan bahwa pandemi Covid-19, membuat adanya penambahan tugas dan fungsi dari Pecalang Desa Pekraman Denpasar, salah satunya
\end{abstract} dengan dibentuk satgas gotong royong di desa adat yang diberi nama Pecalang Wira Praja. Pecalang Wira Praja inilah yang memantau daerah Desa Pekraman Denpasar serta menghimbau masyarakat untuk selalu mematuhi protokol kesehatan. Adanya Pecalang Wira Praja sangat penting karena sampai saat ini Pecalang Wira Praja masih memiliki rasa kewibawaan dari masyarakat Bali sehingga jika Pecalang turun ke masyarakat, cenderung lebih dituruti atau mengikuti apa yang menjadi himbauan dari Pecalang Wira Praja.

\section{A B S T R A C T}

In 2020, precisely in March, Indonesia was shocked by the presence of Covid-19, which claimed many lives, so that the government continued to make policy after policy to break the Covid-19 chain. Based on this, the Bali provincial government involved Pekraman Village by empowering Pecalang. This study aims to find out how Pecalang performs its functions and duties as a traditional security task force in handling the spread of Covid-19 in Pekraman Village, Denpasar. The research method used is descriptive qualitative. The data obtained came from the results of observations, in-depth interviews, and literature studies. The study results indicate that the Covid-19 pandemic has resulted in additional duties and functions of Pecalang Pekraman Village Denpasar, one of which is the formation of a mutual cooperation task force in a traditional village named Pecalang Wira Praja. The Pecalang Wira Praja monitors the Pekraman Village area of Denpasar and urges the public to always comply with health protocols. The existence of Pecalang Wira Praja is fundamental because, until now, Pecalang Wira Praja still has a sense of authority from the Balinese people so that if Pecalang comes down to the community, they tend to be more obeyed or follow the appeal of Pecalang Wira Praja.

Copyright (C) Universitas Pendidikan Ganesha. All rights reserved.

\footnotetext{
* Corresponding author.

E-mail addresses: bayuadhinata@warmadewa.ac.id
} 


\section{Pendahuluan}

Masyarakat yang ada di seluruh belahan dunia tengah menghadapi ancaman wabah virus corona (Covid-19). Salah satu negara dengan jumlah peningkatan kasus Covid-19 yang tinggi adalah Indonesia. Penyebaran yang terjadi di Indonesia berasal dari pelaku perjalanan dari negara atau wilayah terjangkit Covid-19 serta transmisi lokal. Ancaman yang timbul dari pandemi ini selain berdampak pada kesehatan juga pada aspek lainnya seperti: aspek ekonomi sosial, serta kesejahteraan masyarakat Indonesia (Puspawati et al., 2020). Berdasarkan Keputusan Presiden Republik Indonesia Nomor 12 Tahun 2020 tentang Penetapan Bencana Non-Alam Penyebaran Corona Virus Disease 2019 (COVID-19) sebagai Bencana Nasional, Presiden membentuk gugus tugas percepatan penanganan Covid-19 dalam rangka mengkoordinasikan pemerintah pusat dan daerah.

Sejalan dengan hal tersebut, pemerintah daerah memegang peranan penting menetapkan kebijakan untuk mengatur tata cara pencegahan penyebaran virus corona di masing-masing daerahnya. Hal tersebut tentunya menjadi tantangan bagi Provinsi Bali karena sebagian besar pendapatan daerahnya berasal dari sektor pariwisata, sehingga perlu adanya strategi khusus dalam mengatur pola kebiasaan masyarakat dalam beraktivitas. Salah satu upaya Pemerintah Daerah Provinsi Bali menerbitkan beberapa kebijakan untuk diterapkan oleh masyarakat guna mencegah penyebaran kasus Covid- 19 yaitu dengan memberlakukan Pembatasan Kegiatan Masyarakat (PKM), dan yang terbaru saat ini adalah Pemberlakuan Pembatasan Kegiatan Masyarakat (PPKM).

Kasus Covid-19 per tanggal 14 Agustus 2021 terkonfirmasi sebanyak 1.795 orang yang terdiri dari 1.405 orang melalui transmisi lokal, 375 Pelaku Perjalanan Dalam Negeri (PPDN) dan 15 Pelaku Perjalanan Luar Negeri (PPLN) infocorona.baliprov.go.id, Dari 9 kabupaten/kota di Provinsi Bali, Kota Denpasar terbilang cukup tinggi dengan kasus Covid-19 yang terkonfirmasi sejumlah 595 orang pada tanggal 14 Agustus 2021 sehingga jumlah kasus aktif yang tercatat sejumlah 4.959 orang safecity.denpasarkota.go.id. Kondisi tersebut dapat menggambarkan tantangan dalam penanganan pandemi Covid-19 di Kota Denpasar yang tentunya membutuhkan kerjasama dari berbagai pihak serta seluruh lapisan masyarakat.

Untuk mencegah penyebaran virus Covid-19, Gubernur Bali menerbitkan Surat Edaran Nomor 14 Tahun 2021 Tentang Pemberlakuan Pembatasan Kegiatan Masyarakat (PPKM) Level 4 Corona Virus Disease 2019 Dalam Tatanan Kehidupan Era Baru Di Provinsi Bali. Surat Edaran ini mulai berlaku pada tanggal 10 Agustus 2021 sampai dengan pemberitahuan lebih lanjut. Pemerintah Daerah Provinsi Bali mensinergikan kegiatan pencegahan penularan Virus Corona (Covid-19) dengan melibatkan Desa Pekraman yang ada di Bali. Penerapan kebijakan seperti PPKM di desa pekraman tidak bisa dijalankan sendiri oleh pemerintah tetapi perlu kerjasama dengan berbagai pihak baik itu masyarakat, petugas kesehatan maupun petugas keamanan. Pada umumnya Bhabinkamtibmas merupakan petugas keamanan yang ada di desa. Namun di Bali, setiap desa pekraman memiliki petugas keamanan adat berbasis kearifan lokal yang bersifat tradisional dinamakan "Pecalang".

Pecalang merupakan kelompok keamanan tradisional Bali yang bertugas menjaga keamanan dan ketertiban desa adat. Semakin menghilangnya budaya Bali akibat modernisme sangat mengkhawatirkan seperti adanya kejahatan narkotika, terorisme, dan korupsi yang merupakan berbagai ancaman terhadap kebudayaan Bali. Kondisi tersebut yang membuat masyarakat membutuhkan kelompok keamanan tradisional yang mampu menjadi symbol sekaligus benteng untuk menunjukkan kekuatan dari kebudayaan Bali. Pecalang dibentuk berdasarkan tugas, fungsi dan kewajibannya untuk menjadi pionir masyarakat dalam mempertahankan keberadaan budaya Bali (Mahadewi, 2014).

Salah satu kajian yang menyoroti perubahan peran Pecalang adalah penelitian yang dibuat oleh (Astara dan Mardika, 2017) dengan judul Dinamika Peran Pacalang Dalam Menunjang Aktivitas Kepariwisataan di Desa Adat Tuban-Kuta. Dalam kajian ini memaparkan bentuk atau model pacalang desa adat Tuban adalah yang awalnya Pecalang memiliki fungsi "Budaya" dalam menjalankan "swadarmaning agama" namun seiring dengan proses dinamika pariwisata dan "migrasi" pencari kerja di desa adat Tuban, maka terjadilah peralihan fungsi dari fungsi agama 
beralih menjadi fungsi Negara yang dijelmakan dalam bentuk/model Pasukan Keamanan Desa (PKD) di desa adat Tuban. PKD inilah kemudian yang unsurnya dari pemuda dan setelah kawin menjadi Pecalang melakukan tugas multi fungsi di desa adat Tuban untuk menjaga keamanan desa. Bentuk tugas Pecalang antara tugas "Negara" dan tugas "agama" Pecalang desa adat Tuban telah membantu tugas polisi dan hansip dalam menertibkan penduduk pendatang yang berkaitan dengan kegiatan kepariwisataan terutama untuk rumah sewa/kos-kosan setiap bulan. Dinamika pacalang di desa adat Tuban dalam konteks pariwisata berperan untuk menjaga ketertiban dengan menerima komunitas plural. Tarik ulur ketertiban Pecalang di "adat" dan ketertiban "Negara", selanjunya terjadi sintese dan integrasi fungsi pacalang dari fungsi agama masuk ke fungsi "Negara".

Dalam kajian yang berbeda, Pecalang didirikan guna melestarikan ekosistem pantai dan laut. Untuk mewujudkan sasaran tersebut Pecalang segara bekerja sama dengan desa pakraman, desa dinas dan stakeholder, melakukan berbagai praktik sosial pelestarian dituangkan dalam bentuk program yang berfokus pada pelestarian ekosistem pantai dan laut (Atmadja, Atmadja dan Maryati, 2013). Kajian mengenai optimalisasi peran Pecalang di desa pakraman menyatakan keberadaan Pecalang memiliki dasar hukum yang jelas terutama dalam UU No. 2 Tahun 2002 tentang Kepolisian Negara RI dan dalam PERDA Propinsi Bali No. 3 Tahun 2001 tentang Desa Pakraman. Untuk menentukan luas ruang lingkup tugas/kewenangan Pecalang dibidang Adat/Agama dapat menggunakan doktrin Tri Hita Karana sebagai tolak ukurnya. Dengan demikian maka fungsi Pecalang sebagai pembantu kepolisian dalam menjaga keamanan dan ketertiban terurai dalam 3 dimensi yakni; (1) pengaman terhadap parahyangan yaitu hubungan yang seimbang dengan Tuhan Yang Maha Esa. (2) pengamanan terhadap keberadaan pawongan artinya hubungan yang harmonis antara manusia sesam manusia. (3) pengamanan terhadap keperadaan palemahan merupakan hubungan yang harmonis antara manusia dengan lingkungan alam sekitarnya (Setiabudi, Sudirman dan Suryatartha, 2015).

Degung Santikarma (2003) mencatat bahwa pada awalnya untuk menjaga keamanan konferensi tahun 1998 partai Megawati (PDIP) di Bali menjadikan Pecalang sebagai gugus tugas. Sebutan Pecalang mulai dikenal pada saat Kongres PDI Perjuangan yang pada saat itu dilaksanakan di Bali. Pecalang berperan dalam membantu menjaga kelancaran jalannya kongres. Kesuksesannya dalam menjaga kelancaran dan ketertiban kongres membuat Pecalang mulai dikenal. Sosok pria kekar berkacamata hitam yang menggunakan kamen, kain khas Bali dengan saput poleng serta keris di pinggang dan handy-talkie di tangan muncul di tengah momen ini. Lainnya mengatakan bahwa Pecalang merupakan inkarnasi modern dari penjaga istana dan mereka masih bisa mengingat kekerasan tahun 1965 bahwa Pecalang merupakan kebangkitan geng bertanggungjawab untuk melakukan eksekusi terhadap yang dituduh komunis. Oleh karena itu peneliti ingin mengetahui lebih jauh mengenai peran dan fungsi Pecalang yang turut menjadi satuan tugas Covid-19 untuk menjaga keamanan di desa pekraman Denpasar dan bagaimana Pecalang menjalankan fungsi dan tugas sebagai satgas keamanan tradisional dalam penanganan penyebaran Covid-19 di Desa Pekraman Denpasar.

\section{Metode}

Penelitian ini menggunakan pendekatan kualitatif yang menekankan pola eksplorasi dan menggambarkan masalah sosial atau masalah kemanusiaan (Creswell: 2012). Dalam penelitian ini, penelitian kualitatif dipilih karena dapat mengeksplorasi atau menggali data dan informasi secara mendetail terkait tambahan fungsi dan tugas selama pandemi serta cara Pecalang menjalankan fungsi dan tugasnya sebagai satuan tugas keamanan tradisional dalam mencegah penyebaran virus corona di Desa Pekraman Denpasar. Studi kasus merupakan studi yang mengeksplorasi suatu kasus secara mendalam, mengumpulkan informasi secara lengkap dengan menggunakan berbagai prosedur pengumpulan data berdasarkan waktu yang telah ditentukan. Kasus ini dapat berupa suatu peristiwa, aktivitas, proses, dan program (Creswell: 2016). Metode studi kasus digunakan untuk dapat memberikan batasan yang spesifik dalam mengambarkan keadaan Pecalang di Desa Pekraman Denpasar. 
Pengumpulan data pada penelitian ini menggunakan wawancara mendalam dengan melakukan wawancara semi terstruktur yaitu mengajukan beberapa pertanyaan kepada informan terkait tambahan fungsi dan tugas selama pandemi serta cara Pecalang menjalankan fungsi dan tugasnya sebagai satuan tugas keamanan tradisional dalam mencegah penyebaran virus corona di Desa Pekraman Denpasar. Teknik penentuan informan yang dilakukan oleh peneliti dalam penelitian ini adalah teknik purposive sampling dimana informan atau narasumber dipilih berdasarkan pertimbangan dan memiliki tujuan tertentu agar data yang didapat benarbenar nyata serta informan atau narasumber yang dipilih untuk diwawancarai merupakan orangorang yang dianggap mengetahui dan menguasai suatu keahlian atau pekerjaan dibidangnya (Sugiyono, 2010). Informan dalam penelitian ini terdiri dari 3 (tiga) yaitu informan kunci yang mengetahui informasi secara umum dan mengetahui keadaan Pecalang di Desa Pekramann Denpasar secara konseptual, informan utama yaitu informan yang memiliki informasi secara detail serta merupakan aktor utama dan yang terakhir informan pendukung dimana informan pendukung ini dapat memberikan informasi tambahan yang bermanfaat. Wawancara dilakukan secara luring dan daring mengikuti protokol kesehatan yang berlaku. Dimana informan terdiri dari:

1) Informan Kunci terdiri dari Petajuh II yang membidangi pawongan, Pembina Pecalang Wira Praja Desa Pekraman Denpasar, Kasinoman Desa Pekraman Denpasar.

2) Informan Utama: 3 (tiga) Pecalang Desa Pekraman Denpasar.

3) Informan Pendukung: 3 (tiga) masyarakat yang ada di Desa Pekraman Denpasar.

Penelitian ini juga menggunakan data sekunder yang berasal dari buku, jurnal dan artikel mengenai Pecalang dan penyebaran virus Corona (Covid-19).

\section{Hasil dan Pembahasan}

\section{Pecalang sebagai satuan keamanan tradisional}

Desa adat di Bali memiliki beberapa lembaga adat, salah satunya yaitu Pecalang. Keberadaan Pecalang menjadi semakin kuat dengan adanya Peraturan Daerah Provinsi Bali Nomor 4 Tahun 2019 tentang Desa Adat yang dijelaskan pada pasal 1 angka 20: "Pecalang Desa Adat atau Jaga Bhaya Desa Adat atau sebutan lain adalah satuan tugas keamanan tradisional Bali yang dibentuk oleh Desa Adat yang mempunyai tugas untuk menjaga keamanan, ketentraman dan ketertiban masyarakat dalam wilayah atau wewidangan Desa Adat. Pecalang berasal dari kata celang dan celing serta mendapat awalan pe yang secara umum diartikan sebagai orang yang mempunyai penglihatan tajam baik di tempat gelap maupun terang. Pecalang terbagi dalam beberapa asal kata yakni (Windia, 2002):

1) Celang, menunjuk kepada penglihatan yang sangat tajam. Orang yang celang dapat membaca rangkaian huruf dengan gampang walaupun ditulis lebih kecil dari biasanya.

2) Celing, selain bersangkutan dengan keadaan mata juga ada hubungannya dengan akal. Celing bukan saja berarti jeli melihat sesuatu namun juga banyak akal. Orang celing bukan hanya melek huruf tetapi juga terampil membaca situasi dan kondisi lingkungan secara akurat sehingga terhindar dari bahaya. Oleh karena itu, orang yang celang dan celing biasanya tidak sombong melainkan ramah lingkungan.

3) Celong, berarti kebalikan dari pengertian celang dan celing. Sifatnya yang tidak boleh dimiliki oleh seorang Pecalang karena sesana Pecalang atau kode etik Pecalang dan juga kata celong digunakan untuk mayat. Mayat atau jenasah seseorang yang telah meninggal itu celong sehingga mudah di serong ke kiri atau kanan sesuai dengan keinginan atau kepentingan seseorang.

Secara sederhana dapat dikatakan bahwa Pecalang adalah perangkat prajuru (pimpinan) desa adat yang dibentuk oleh desa adat atau pekraman untuk membantu tugas-tugas prajuru di bidang keamanan dan ketertiban intern desa adat khususnya terkait dengan pelaksanaan adat dan Agama Hindu terutama dalam hal menjaga keamanan dan ketertiban yang berhubungan dengan Tri Mandala dan Tri Hita Karana. Secara filosofis, keberadaan pecalang dapat dikaitkan dengan filosofi Tri Hita Karana yang menjadi landasan desa pakraman. Filosofi Tri Hita Karana adalah filosofi Hindu yang mengajarkan bahwa, kesejahteraan umat manusia di dunia ini hanya dapat dicapai apabila terjadi: (1) keseimbangan hubungan manusia dengan Tuhan; (2) 
keseimbangan hubungan manusia dengan lingkungannya; (3) keseimbangan hubungan manusia dengan sesamanya. Keseimbangan atau suasana harmonis dalam hubungan tersebut secara kongkrit dapat diterjemahkan sebagai suasana tertib, aman dan damai (trepti, sukerta sekala niskala). Demikianlah, untuk dapat mencapai suasana tertib, aman dan damai di dalam kehidupan desa pakraman (kasukertan desa), maka diperlukan adanya perangkat keamanan desa pakraman yang disebut Pecalang.

Keberadaan Pecalang memiliki hubungan yang erat dengan kehidupan keagamaan (parhyangan), hubungan antara manusia dengan manusia lainnya (pawongan), serta hubungan antara manusia dengan lingkungannya (palemahan). Pecalang memiliki tugas dan fungsi tersendiri. Dalam Lontar Purwadigama disebutkan kewajiban Pecalang adalah sebagai berikut:

1) Ngupadesa, Pecalang harus selalu dekat dengan desa pekraman dan warganya. Dengan dekat dan diam di desa, ini lebih terjamin adanya komunikasi dalam rangka mengarahkan krama (warga) desa.

2) Atitikarma, Pecalang hendaknya selalu memberikan petunjuk yang benar kepada krama desa. Petunjuk tersebut bisa berupa arah, maupun keteladanan. Pecalang harus memberikan contoh yang baik bagi warga desa, karena memiliki kharisma dan berwibawa.

3) Jaga Baya Desa, Pecalang wajib menjaga keamanan desa dengan melakukan amarah desa yakni, melakukan ronda atau keliling desa pekraman jangan sampai ada bahaya.

Tabel 1.

Fungsi dan tugas pecalang sebelum dan sesudah Pandemi Covid-19

\begin{tabular}{cll}
\hline No. & \multicolumn{1}{c}{ Sebelum Pandemi Covid-19 } & \multicolumn{1}{c}{ Fungsi dan Tugas Pecalang } \\
\cline { 2 - 3 } & $\begin{array}{l}\text { Memantau dan mengamankan } \\
\text { upacara keagaman serta turut } \\
\text { membantu dalam mengatur lalu } \\
\text { lintas }\end{array}$ & Memantau kegiatan masyarakat \\
\hline 2. & & $\begin{array}{l}\text { Memantau masyarakat di mana boleh } \\
\text { berjualan }\end{array}$ \\
\hline 3. & $\begin{array}{l}\text { Berpatroli ke pura-pura untuk melihat } \\
\text { situasi di sana agar pratima atau arca agar } \\
\text { tetap aman }\end{array}$ \\
\hline 5. & $\begin{array}{l}\text { Menghimbau dan membina masyarakat } \\
\text { agar tidak melanggar protokol kesehatan }\end{array}$ \\
\hline 5. & $\begin{array}{l}\text { Mensosialisasikan kebijakan yang } \\
\text { diterapkan oleh pemerintah }\end{array}$ \\
\hline
\end{tabular}

Berdasarkan hasil wawancara penulis dengan Bapak Anak Agung Ngurah Sudiasa selaku Pembina Pecalang Desa Pekraman Denpasar, mengatakan bahwa tugas dan fungsi Pecalang sebelum adanya pandemi yaitu memantau dan mengamankan upacara keagamaan serta turut membantu dalam mengatur lalu lintas. Babinsa setempat tetap bertugas namun dibantu oleh Pecalang sehingga pekerjaan itu akan terasa ringan. Pada saat terdapat upacara keagamaan, Pecalang desa memantau terlebih dahulu karena di tiap banjar yang ada di wilayah Desa Pekraman sudah memiliki Pecalang. Apabila Pecalang banjar merasa kewalahan, maka akan dibantu oleh Pecalang desa (Pecalang Wira Praja).

Desa Pekraman Denpasar terdapat Pecalang desa dan banjar. Pecalang desa merupakan kumpulan dari Pecalang di banjar-banjar. Desa Pekraman Denpasar terdiri dari 105 banjar. Adapun sistem perekrutan menjadi Pecalang di desa adat yaitu ditunjuk oleh banjar adat dan mendapatkan rekomendasi dari kelihan adat. Jika sudah mendapatkan rekomendasi dari kelihan adat selanjutnya jero bendesa yang akan membuatkan SK serta surat tugas sehingga Pecalang tidak arogansi saat bekerja di lapangan terutama menghadapi masyarakat. Berikut lampiran daftar wawancra yang dilakukan dengan masyarakat Desa Pekraman Denpasar. Berikut hasil tanya jawab yang dilakukan dengan masyarakat Pekraman Denpasar seperti terlihat pada Tabel 2. 
Tabel 2.

Hasil wawancara dengan masyarakat

\begin{tabular}{|c|c|c|c|c|}
\hline \multirow[t]{2}{*}{ No. } & \multicolumn{3}{|c|}{ Hasil Wawancara } & \multirow[t]{2}{*}{ Kategori } \\
\hline & 1 & 2 & 3 & \\
\hline 1. & Sejak 2020 & $\begin{array}{l}\text { Nike kalau nggak salah tahun } \\
2020,2020 \text { sudah ada. Waktu } \\
\text { Covid pertama kali muncul itu } \\
\text { kan tahun } 2020 \text { mulai disan } \\
\text { dah Pecalang banjarnya } \\
\text { diberdayakan untuk jaga di } \\
\text { masing-masing dusun dan juga } \\
\text { pernah untuk mewakili desa } \\
\text { dinas juga pernah. Setahu } \\
\text { tiang nike tahun } 2020 \text { kalau } \\
\text { nggak salah bulan April } 2020 \\
\text { kalau nggak salah } \\
\text { diberdayakan itu. }\end{array}$ & $\begin{array}{l}\text { Ketika } \\
\text { timbulnya covid }\end{array}$ & $\begin{array}{l}\text { Munculnya } \\
\text { memberdayakan } \\
\text { Pecalang }\end{array}$ \\
\hline
\end{tabular}

\begin{tabular}{|c|c|c|c|c|}
\hline 2. & $\begin{array}{l}\text { Kerjanya bagus } \\
\text { karena berjaga } 24 \\
\text { jam. Pekerjaan } \\
\text { pecalang itu menjaga } \\
\text { desa yang keluar } \\
\text { masuk desa dan juga } \\
\text { mendata orang-orang } \\
\text { yang baru datang } \\
\text { (pendatang) }\end{array}$ & $\begin{array}{l}\text { Ya bagus, membantu juga dia. } \\
\text { Jadi kalau ada informasi apa } \\
\text { dari baik Desa Dinas maupun } \\
\text { Desa Adat kelian adat yang } \\
\text { menindaklanjuti ke Pecalang } \\
\text { sebagai petugas PPKM dan } \\
\text { mereka mengikuti prosedur } \\
\text { yang ada jadi sangat-sangat } \\
\text { membantu Pecalang yang ada } \\
\text { di dusun. }\end{array}$ & $\begin{array}{l}\text { Mendekati atau } \\
\text { memberi saran } \\
\text { kepada warga } \\
\text { yang terpapar } \\
\text { dengan dibantu } \\
\text { data dari dinas. }\end{array}$ & Kinerja Pecalang \\
\hline 3. & $\begin{array}{l}\text { Sebelumnya } \\
\text { membantu } \\
\text { mengamankan dalam } \\
\text { upacara adat seperti } \\
\text { odalan dan upacara } \\
\text { pernikahan dan } \\
\text { sekarang lebih bagus } \\
\text { lagi karena desa lebih } \\
\text { terjaga aman dari } \\
\text { orang-orang baru } \\
\text { semenjak ada PPKM. } \\
\text { Setelahnya menjadi } \\
\text { lebih tegas lagi. }\end{array}$ & $\begin{array}{l}\text { Perbedaannya ya bertambah } \\
\text { jadinya pekerjaan mereka, } \\
\text { kalau dulu mereka kan khusus } \\
\text { menangani adat saja misalnya } \\
\text { ada upacara adat kan gitu. } \\
\text { Kalau sekarang kan nambah } \\
\text { lagi jadinya lebih berbaur } \\
\text { kemasyarakat membantu baik } \\
\text { kelian adat maupun kepala } \\
\text { dusun dalam memonitoring } \\
\text { warga yang terpapar, } \\
\text { menginformasikan kepada } \\
\text { kelian gitu jadinya nambah } \\
\text { tugasnya pecalang. }\end{array}$ & $\begin{array}{l}\text { Rasanya tidak } \\
\text { ada, cuman } \\
\text { penambahan } \\
\text { tugas terhadap } \\
\text { pecalang di } \\
\text { waktu sebelum } \\
\text { covid tidak } \\
\text { mencari orang, } \\
\text { kalau sekarang } \\
\text { mencari orang. } \\
\text { Kalau ada } \\
\text { warganya yang } \\
\text { tepapar covid } \\
\text { pecalang } \\
\text { bergerak dari } \\
\text { data yang ada } \\
\text { di dinas. }\end{array}$ & $\begin{array}{l}\text { Perbedaan fungsi } \\
\text { dan tugas pecalang } \\
\text { sebelum dan } \\
\text { sesudah adanya } \\
\text { pandemi }\end{array}$ \\
\hline 4. & $\begin{array}{l}\text { Melakukan } \\
\text { pengawasan kepada } \\
\text { daerha yang terkena } \\
\text { covid agar tidak ada } \\
\text { yang masuk } \\
\text { kedaerah tersebut, } \\
\text { Pendataan kepada } \\
\text { warga ketika masuk } \\
\text { ke daerah tersebut. } \\
\text { patroli di daerah } \\
\text { tersebut. }\end{array}$ & $\begin{array}{l}\text { ya pada saat-saat tertentu ya } \\
\text { kita ajak dia sidak itu kalua } \\
\text { ada warga yang tiddak pakai } \\
\text { masker ya diberi edukasi biar } \\
\text { selalu menggunakan masker, } \\
\text { kalau kita punya masker lebih } \\
\text { ya kita sumbangkan ke } \\
\text { mereka yang kebetulan tidak } \\
\text { pakai masker dan mereka juga } \\
\text { ikut turun ke rumah-rumah } \\
\text { kalua ada yang terpapar. } \\
\text { Mereka ikut dalam kegiatan } \\
\text { penyemprotan. }\end{array}$ & $\begin{array}{l}\text { Penambahan } \\
\text { tugas terhadap } \\
\text { pecalang di } \\
\text { waktu sebelum } \\
\text { covid tidak } \\
\text { mencari orang, } \\
\text { kalau sekarang } \\
\text { mencari orang. } \\
\text { Kalau ada } \\
\text { warganya yang } \\
\text { tepapar covid } \\
\text { pecalang } \\
\text { bergerak dari }\end{array}$ & $\begin{array}{l}\text { Tambahan fungsi } \\
\text { dan tugas pecalang } \\
\text { selama pandemi }\end{array}$ \\
\hline
\end{tabular}




\begin{tabular}{|c|c|c|c|c|}
\hline & & & $\begin{array}{l}\text { data yang ada } \\
\text { di dinas. }\end{array}$ & \\
\hline 5. & $\begin{array}{l}\text { Penjagaan lebih } \\
\text { diperketat, lalu ada } \\
\text { shif itu diantara } \\
\text { pecalangnya, dengan } \\
\text { pembagian kegiatan } \\
\text { setengah hari udah } \\
\text { bergantian shif. } \\
\text { Tugasnya yiatu } \\
\text { dengan keliling } \\
\text { daerah dan mendata } \\
\text { warga yang dating } \\
\text { denga nada } \\
\text { pembagian tugas } \\
\text { dianntara pecalang } \\
\text { agar setiap hari ada } \\
\text { pecalang yang } \\
\text { bertugas. }\end{array}$ & $\begin{array}{l}\text { Selama ini belum begitu } \\
\text { karena masih lebih banyak ke } \\
\text { desa dinas, jadinya dari desa } \\
\text { adatnya belum terlalu karena } \\
\text { saya melihat desa adat } \\
\text { aktifnya lebih di patroli dalam } \\
\text { rangka penutupan pedagang } \\
\text { mengarahkan pedagang gitu } \\
\text { itu aktifnya dia. Kalau untuk } \\
\text { penyempropatannya itu desa } \\
\text { adat itu belum. Cuma itudah } \\
\text { patroli menghimbau } \\
\text { pedagang. Tapi kalau untuk } \\
\text { penyemprotan dengan skala } \\
\text { desa, desa adatnya ikut } \\
\text { membantu desa dinas. Desa } \\
\text { Dinas ini kan ada program2 } \\
\text { penyemprotan jadinya desa } \\
\text { adat ikut bersinergi. Tapi } \\
\text { kalua untuk ke dusun-dusun } \\
\text { belum, masih pecalang yang } \\
\text { ada di dusun saja. }\end{array}$ & $\begin{array}{l}\text { Membantu } \\
\text { mencari yang } \\
\text { terpapar covid } \\
\text { sesuai data dari } \\
\text { dinas. Nanti } \\
\text { patus } \\
\text { koordinasi } \\
\text { dengan } \\
\text { pecalang untuk } \\
\text { mengetahui } \\
\text { alamatnya. }\end{array}$ & $\begin{array}{l}\text { Pelaksanaa fungsi } \\
\text { dan tugas pecalang } \\
\text { selama pandemi }\end{array}$ \\
\hline 6. & $\begin{array}{l}\text { Pendataan dengan } \\
\text { turun langsung, } \\
\text { melakukan } \\
\text { pengecekan langsung } \\
\text { ke warga yang datang } \\
\text { dengan mengecek } \\
\text { KTP, surat vaksin, } \\
\text { dan apabila dia tidak } \\
\text { membawa maka } \\
\text { diminta untuk balik. } \\
\text { Dan melakuka } \\
\text { penjagaan di daerah } \\
\text { yang ada warga yang } \\
\text { terkena covid dan } \\
\text { dilarang masuk } \\
\text { disekitar daerah } \\
\text { tersebut dan ada } \\
\text { penjagaan ketat dan } \\
\text { ditutup daerah } \\
\text { tersebut jika zona } \\
\text { merah di gang } \\
\text { tersebut. dan apabila } \\
\text { perlu sesuatu maka } \\
\text { digantung dipagar } \\
\text { tersebut. }\end{array}$ & $\begin{array}{l}\text { Kalau jalur koordinasi itu } \\
\text { biasanya dapat informasi dari } \\
\text { kepala dusun, kepala dusun } \\
\text { nanti menginformasikan ke } \\
\text { pecalang ada warga yang } \\
\text { terpapar Covid dengan } \\
\text { memberikan nama dan alamat } \\
\text { kemudian nanti jika ada } \\
\text { bantuan-bantuan dari } \\
\text { pemerintah penyalurannya } \\
\text { biasanya pecalang yang } \\
\text { membawa ke tempat warga } \\
\text { yang terpapar itu. Kayak } \\
\text { sekarang ini kan yang isolasi } \\
\text { mandiri dapat bantuan } \\
\text { konsumsi nah itulah pecalang } \\
\text { yang mendistribusikan ke } \\
\text { warga-warga yang isolasi } \\
\text { mandiri itu. }\end{array}$ & $\begin{array}{l}\text { Aturan ada di } \\
\text { dinas, jadi } \\
\text { bagaimana } \\
\text { mengedukasi } \\
\text { warga untuk } \\
\text { isolasi, karena } \\
\text { itugasnya } \\
\text { pecalang. }\end{array}$ & $\begin{array}{l}\text { Pelaksanaa fungsi } \\
\text { dan tugas pecalang } \\
\text { selama pandemi }\end{array}$ \\
\hline 7. & $\begin{array}{l}\text { Penting sekali, tanpa } \\
\text { pecalang nanti takut } \\
\text { nggak ada yang jaga } \\
\text { sehingga nggak bisa } \\
\text { menekan } \\
\text { penyebaran Covid- } \\
19 .\end{array}$ & $\begin{array}{l}\text { Ya penting karena boleh } \\
\text { dibilang sampai saat ini } \\
\text { pecalang itu masih punya dan } \\
\text { ada rasa kewibawaan dari } \\
\text { masyarakat Bali jadi kalua } \\
\text { pecalang yang turun jadi } \\
\text { masyarakat itu cenderung } \\
\text { lebih untuk menurut, kalua } \\
\text { pecalang, kelian adat, kepala } \\
\text { dusun itu cenderung mereka }\end{array}$ & $\begin{array}{l}\text { Memang } \\
\text { penting }\end{array}$ & $\begin{array}{l}\text { Opini masyarakat } \\
\text { mengenai } \\
\text { pentingnya } \\
\text { keberadaan } \\
\text { Pecalang }\end{array}$ \\
\hline
\end{tabular}




\begin{tabular}{|c|c|c|c|c|}
\hline & & $\begin{array}{l}\text { lebih mengikutilah apa yang } \\
\text { jadi himbauan makanya } \\
\text { pecalang itu penting. }\end{array}$ & & \\
\hline 8. & $\begin{array}{l}\text { Membatasi agar tidak } \\
\text { ada kerumunan, } \\
\text { melakukan } \\
\text { pendataan, } \\
\text { mengawasi agar } \\
\text { ketika ada upacara } \\
\text { adat tidak lebih dari } \\
20 \text { orang. Gaji dari } \\
\text { warga sini nggak, } \\
\text { tapi kalau banjarnya } \\
\text { ada upacaranya } \\
\text { nggak dapat. } \\
\text { Palingan dapat } \\
\text { seikhlasnya ada juga } \\
\text { dapat rokok. }\end{array}$ & $\begin{array}{l}\text { Selama PPKM ini kan ya satu } \\
\text { jaga dipos, dimasing-masing } \\
\text { dusun, kemudian patroli } \\
\text { menghimbau pedagang } \\
\text { menghimbau warga yang } \\
\text { nggak pakai masker, } \\
\text { mengedukasi yang } \\
\text { berkerumun nah seperti itu. } \\
\text { Kalua ada yang terpapar yang } \\
\text { perlu disemprot ya mereka } \\
\text { ikut juga membantu }\end{array}$ & $\begin{array}{l}\text { Yang keras itu } \\
\text { mengedukasi } \\
\text { warga sesuai } \\
\text { dengan aturan } \\
\text { dinas agar } \\
\text { tidak meluas } \\
\text { penyebaran } \\
\text { covid. Dan } \\
\text { meminta warga } \\
\text { untuk mentaati } \\
\text { prokes }\end{array}$ & $\begin{array}{l}\text { Pelaksanaa fungsi } \\
\text { dan tugas pecalang } \\
\text { selama pandemi }\end{array}$ \\
\hline 9. & $\begin{array}{l}\text { Menurut saya masih } \\
\text { harus diperbaiki lagi } \\
\text { karena pas awal } \\
\text { Covid-19 } \\
\text { pengawasannya lebih } \\
\text { ketat namun } \\
\text { sekarang sudah tidak } \\
\text { terlalu ketat }\end{array}$ & $\begin{array}{l}\text { Belum sih belum cuman ya } \\
\text { keberadaan pecalang itu perlu } \\
\text { mungkin kalau nggak ada } \\
\text { pecalang penyebarannya } \\
\text { semakin banyak, dengan } \\
\text { adanya pecalang mungkin } \\
\text { memang masih belum bisa } \\
\text { menekan tapi sangat } \\
\text { membantu lah }\end{array}$ & $\begin{array}{l}\text { Keberhasikan } \\
\text { itu jauh, kalau } \\
\text { penurunan } \\
\text { baru ada. } \\
\text { Karena kita } \\
\text { nggak tau besok } \\
\text { gimana ya. } \\
\text { Penurunan } \\
\text { signifikan ada } \\
\text { dari gerakan } \\
\text { itu. }\end{array}$ & Kinerja Pecalang \\
\hline
\end{tabular}

\section{Pecalang sebagai modal sosial menghadapi pandemi}

Sebelum adanya pandemi, Pecalang merupakan perangkat banjar dan desa yang membantu di bidang keamanan banjar dan desa seperti mengamankan jalannya upacara adat namun setelah adanya pandemi, Pecalang memantau dan mengedukasi masyarakat untuk menerapkan protokol kesehatan, menertibkan masyarakat yang berjualan serta Pecalang berpatroli ke pura-pura untuk menjaga pratima atau arca agar tetap aman. Pecalang juga diberikan bimbingan terkait dengan permasalahan mengatur lalu lintas serta etika dan sopan santun menjadi Pecalang agar tidak adanya arogansi kepada masyarakat.

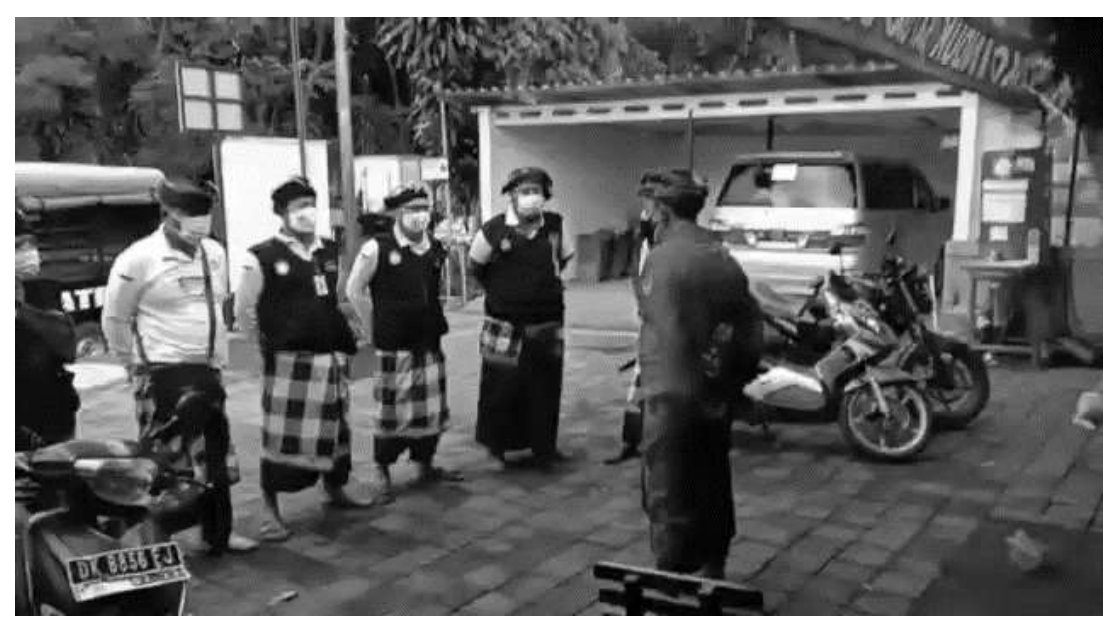

Gambar 1.

Pemberian arahan sebelum patroli 
Pecalang merupakan bagian dari masyarakat yang sehari-harinya melakukan interaksi secara normal. Pembina Pecalang Desa Pekraman Denpasar mengatakan bahwa, dalam upaya pencegahan Covid-19 Pecalang difungsikan karena Pecalang disebut sebagai polisi Adat Bali dan ditakutkan oleh masyarakat karena pakaiannya yang penuh karisma dan berwibawa. Selama pandemi, tugas pokok Pecalang adalah menghimbau dan membina masyarakat agar tidak melanggar protokol kesehatan. Sama halnya disampaikan oleh Petajuh II Desa Pekraman Denpasar (wakil yang membidangi pawongan atau yang berkaitan dengan orang-orang), beliau mengatakan bahwa adanya Covid-19 membuat Pecalang bersinergi dengan pemerintah baik itu desa maupun kota. Hal ini dapat dihubungkan dengan konsep modal sosial menurut Woolcock (1998) yang memberikan pernyataan bahwa modal sosial merupakan mekanisme dan hubungan antara kepercayaan, norma, dan jaringan dalam pengaturan sosial di suatu daerah. Nilai-nilai ini dapat dimanfaatkan dalam hal manajemen bencana. Modal sosial dapat menjadi modal kuat yang dibangun oleh masyarakat setempat dan organisasi-organisasi yang ada (Rijanta et. al., 2018). Hal ini tercermin pada Keputusan Bersama Gubernur Bali dan Majelis Desa Adat Provinsi Bali tentang Pembentukan Satuan Tugas Gotong Royong Pencegahan Covid-19 Berbasis Desa Adat Di Bali. Satgas Gotong Royong di ingkungan desa adat tersebut memiliki tugas untuk memberdayakan seluruh warga desanya agar bergotong royong bersama dalam mencegah penyebaran Covid-19 baik secara secara 'sekala' atau jasmani/nyata maupun secara 'niskala' atau rohani/tidak nyata. Terkait tugasnya secara nyata, satgas di desa adat melaksanakan berbagai upaya sosialisasi, edukasi, pencegahan, pengawasan serta pembinaan terkait dengan Covid-19. Dalam pelaksanaannya, Pecalang atau petugas keamanan adat Bali berperan sebagai ujung tombak dalam pengawasan serta pembinaan yang dilakukan bersama dengan sejumlah unsur terkait seperti TNI, Polri dan Linmas. (Astawa dan Sadri, 2020).

Pecalang di Desa Pekraman Denpasar memiliki satgas gotong royong yang dibentuk oleh bendesa adat bernama Pecalang Wira Praja. Arti dari Pecalang Wira Praja yaitu wira yang berarti pandai dan praja yang berarti rakyat. Wira Praja artinya rakyat yang pandai serta memiliki tata krama yang baik. Pecalang Wira Praja memberikan himbauan kepada seluruh masyarakat agar tetap mematuhi protokol kesehatan dengan tetap memakai masker dengan benar dan menjaga jarak untuk memutus rantai penyebaran Covid-19. Pecalang Wira Praja memberikan himbauan untuk tetap mematuhi protokol kesehatan dengan cara berpatroli dan memberikan masker untuk masyarakat yang tidak menggunakan masker.

Patroli dilaksanakan pada hari senin, rabu, dan jumat. Dengan tugasnya yang berat, Pecalang Wira Praja diberikan sejenis oleh- oleh berupa uang Rp 510.000,00 perbulan. Jumlah anggota Pecalang Wira Praja yaitu 25 orang (5 regu dan 3 shift). Pecalang yang dijadikan sebagai satgas gotong royong merupakan orang-orang yang bertanggungjawab dan membawa nama banjar masing-masing. Pecalang Wira Praja tetap berkoordinasi dengan petugas dalam hal ini BPBD kemudian PMI dan juga Puskesmas kalau ada memang masyarakat yang terpapar Covid-19. Petajuh II Desa Pekraman Denpasar mengatakan bahwa di desa adat dengan kondisi Covid-19 saat ini, membentuk namanya satgas Covid-19 dari Pecalang yang dinamai Pecalang Wira Praja. Tugas dari Pecalang Wira Praja yaitu memantau di seputaran wilayah Desa Adat Denpasar dan juga membantu dalam pemberlakuan penyekatan jalan yang bersinergi dengan dinas perhubungan, bidang kesehatan, dan BPBD. Selain itu, Pecalang Wira Praja juga mendampingi pada saat penyemprotan dari pihak desa (Sudiasa, 2021). Dimana ini berhubungan dengan pendapat Bourdieu, (1980) yang menyatakan bahwa social capital merupakan sumber daya yang terdapat pada individu maupun kelompok masyarakat yang terhubung dalam sebuah jaringan (network), yang terkait dalam relasi yang bersifat institusional maupun non- institusional, dan saling menguntungkan satu sama lain (Dollu, 2019).

Pecalang bersinergi dengan pemerintah kota seperti Badan Penanggulangan Bencana Daerah (BPBD) Provinsi Bali untuk menangani penyebaran Covid-19 di Desa Pekraman Denpasar (Sucita, 2021). Apabila terdapat masyarakat yang terkena Covid-19, Pecalang mencatat dan melaporkan ke desa. Untuk para isoman akan diberikan makanan dan Pecalang yang mengantarkan makanan ke rumah isoman. Tugas dari Pecalang pada dasarnya adalah ngayah karena memang tidak digaji. Jika ada yang tidak mematuhi protokol kesehatan, maka akan dihimbau kembali (Arsana, 2021). Dalam penanganan penyebaran Covid-19 di Desa Pekraman 
Denpasar Pecalang Wira Praja melakukan pengecekan langsung ke warga dengan melakukan pengecekan KTP dan surat vaksin. Selain itu, Pecalang Wira Praja melakukan penjagaan di daerah yang terkena Covid dan dilarang masuk daerah tersebut. Penjagaan yang dilakukan secara ketat. Dalam menangani penyebaran Covid-19 di Desa Pekraman Denpasar, Pecalang Wira Praja membatasi kerumunan, melakukan pendataan, serta mengawasi agar ketika terdapat upacara adat tidak melebihi 20 orang (Adi, 2021). Penanganan penyebaran Covid-19 di Desa Pekraman Denpasar, Pecalang Wira Praja melakukan sidak masker kemudian diberikan edukasi agar menggunakan masker. Pecalang Wira Praja juga melakukan patroli untuk mengarahkan dan menghimbau pedagang agar menutup tokonya sesuai ketentuan PPKM. Adanya Pecalang Wira Praja sangat penting karena sampai saat ini Pecalang Wira Praja masih memiliki rasa kewibawaan dari masyarakat Bali sehingga jika Pecalang turun ke masyarakat, cenderung lebih dituruti atau mengikuti apa yang menjadi himbauan dari Pecalang Wira Praja (Budiarta, 2021).

\section{Simpulan dan Saran}

Adanya pandemi Covid-19, membuat adanya penambahan tugas dan fungsi dari Pecalang Desa Pekraman Denpasar, salah satunya dengan dibentuk satgas gotong royong di desa adat yang diberi nama Pecalang Wira Praja. Pecalang Wira Praja inilah yang memantau daerah Desa Pekraman Denpasar dengan berpatroli. Selain itu, Pecalang Wira Praja juga menghimbau masyarakat agar selalu menerapkan protokol kesehatan. Kegiatan yang dilakukan Pecalang Wira Praja selama ini belum sepenuhnya berhasil secara maksimal untuk menekan kasus Covid-19 karena tergantung dari masyarakat itu sendiri. Kalau masyarakat disiplin menjalankan protokol kesehatan dan juga sudah menjaga imun tubuh, maka niscaya tidak akan terkena virus. Apabila imun tubuh tidak baik, otomatis kasus dari Covid-19 akan meningkat. Semuanya kembali lagi ke imun tubuh masing-masing. Namun dengan adanya Pecalang Wira Praja, sudah membantu pencegahan penyebaran Covid-19 di Desa Pekraman Denpasar.

\section{Ucapan Terima kasih}

Penulis mengucapkan banyak terimakasih kepada Direktorat Jenderal Pendidikan Tinggi, Riset dan Teknologi dan Direktorat Pembelajaran dan Kemahasiswaan.

\section{Daftar Rujukan}

Astara, I. W. W., \& Mardika, I. M. (2017). Dinamika Peran Pacalang dalam Menunjang Aktivitas Kepariwisataan di Desa Adat Tuban-Kuta. Wicaksana, Jurnal Lingkungan \& Pembangunan, 1(1), 53-71.

Astawa, D. N. W., \& Sadri, N. W. (2020). Pengaturan Pencegahan dan Pengendalian Gering Di, Agung Covid- Desa, Wewidangan Pucaksari, Adat Busungbiu, Kecamatan Buleleng, Kabupaten Buleleng. hal. 162-168.

Atmadja, A. T., Atmadja, N. B., \& Maryati, T. (2013). Pecalang Segara: Satuan Tradisional Penjaga Kelestarian Lingkungan Pantai dan Laut: Studi Kasus Di Desa Pakraman Pemuteran, Grokgak, Buleleng, Bali. Jurnal Bumi Lestari, 13(1), 174-184.

Dollu, E. B. S. (2019). Modal Sosial: Studi Tentang Kumpo Kampo Sebagai Strategi Melestarikan Kohesivitas pada Masyarakat Larantuka di Kabupaten Flores Timur. Warta Governare, 1(1), 59-72.

Mahadewi, N. M. A. S. (2014). Pecalang Simbol Kekuatan Budaya Bali. Jurnal Ilmiah Sosiologi (Sorot), 1(2), 71-79.

Hamonangan, B. N., Frederic R., Simanungkalit, J. O. M., Relieyan, R. H., \& Alam, R. J. (2021). Keterlibatan Polisi Adat dalam Pencegahan Penularan COVID-19 di Indonesia. 1-13.

Info Corona Pemerintah Provinsi Bali. 2021. Update Penanggulangan Covid-19. URL: https://infocorona.baliprov.go.id/. Diakses tanggal 3 September 2021

Pramana, G. I. (2016). Pecalang: Dinamika Kontestasi Kekuasaan di Bali. Lakon: Jurnal Kajian Sastra dan Budaya, 1(1), 21-28.

Puspawati, D. A. et al. (2020). Sinergi Pemerintah Berbasis Adat Dalam Upaya Penanganan Covid19. Prosiding Webinar Nasional Universitas Mahasaraswati Denpasar 2020. 26, Juni 2020, Denpasar, Indonesia, hal. 
143-149.

Rijanta, \& Hizbaron, M. B. (2018). Modal Sosial dalam Manajemen Bencana. Yogyakarta: Gadjah Mada University Press.

Santikarma, D. (2003). The Model Milita: A New Security Force In Bali Is Cloaked In Tradition. Inside Indonesia, edisi 73 (Januari-Maret).

Setiabudi, I. K. R., Sudirman, T. \& Suryatartha, I. W. (2015) Pokok-Pokok Konsepsi Kerawanan yang Perlu di Waspadai di Bali (Optimalisasi Peran "Pecalang" di Desa Pakraman).

Windia, W. P. (2002). Celang, Celing, Celong, dan Pecalang. Bali Post, 12 Mei 2002. 